\title{
CHANGES IN SOIL PH, POLYPHENOL CONTENT AND MICROBIAL COMMUNITY MEDIATED BY EUCALYPTUS CAMALDULENSIS
}

\author{
SOUMARE, A. $.^{1,2^{*}}-$ SALL, S. N. ${ }^{3}-$ SANON, A. ${ }^{4}$ - CISSOKO, M. ${ }^{2}-$ HAFIDI, M. ${ }^{5}-$ NDOYE, I. ${ }^{1,2}-$ \\ DUPONNOIS, R. ${ }^{6}$ \\ ${ }^{I}$ Departement de Biologie Végétale, Faculté des Sciences et Techniques, Université Cheikh Anta \\ Diop, BP 5005, Dakar-Fann, Sénégal
}

${ }^{2}$ Laboratoire Commun de Microbiologie (LCM, IRD/ISRA/UCAD), Bel-Air BP 1386, CP 18524, Dakar-Sénégal

${ }^{3}$ Université Gaston Berger de Saint-Louis, Section Production Végétale et Agronomie, UFR S2ATA, B.P. 234 Saint-Louis

(phone: +221-33961-2360 (stand), +221-77562-0702 (mob); fax: +221-33961-1884)

${ }^{4}$ Institut de Recherche pour le Développement (IRD), Centre de Ouagadougou, 01 BP 182 Ouagadougou, Burkina Faso

${ }^{5}$ Laboratoire Ecologie \& Environnement (Unité associée au CNRST, URAC 32), Faculté des Sciences Semlalia. Université Cadi Ayyad, Marrakech, Maroc.

(phone/fax: +212-52443-7665)

${ }^{6}$ IRD UMR 113 CIRAD/IRD/SUPAGRO/UM2/USC INRA. Laboratoire des Symbioses Tropicales et Méditerranéennes (LSTM), TA-82/j, Campus International de Baillarguet, 34398 Montpellier Cedex 5, France

*Corresponding author

e-mail:ablaysoumare@yahoo.fr

(fax: +221-33832-1675/33849-3302)

(Received $4^{\text {th }}$ Aug 2015; accepted $5^{\text {th }}$ Mar 2016)

\begin{abstract}
Eucalyptus camaldulensis has been the main exotic species planted in reforestation programs in the tropics due to its fast growth and adaptability to climate variations. Based on the premise that the conversion from natural grazed pastures to commercial Eucalyptus plantations generates significant changes in soil properties, we assessed the impact of this exotic plantation on soil chemical and biological indicators. The study was conducted in 6 plantations across Senegal following a decreasing rainfall gradient from south to north. The plantations were divided in three lots according to their age: young plantations (established in 2003, 6 years old); intermediate plantations (established in 1998, 11 years old) and old plantations (established in 1982 and 1983, 26 years old). Our results clearly showed that $E$. camaldulensis plants significantly modified soil $\mathrm{pH}$ and soil bacterial community at all sites regardless of the age of the plantation. Microbial biomass (assessed by substrate-induced respiration), community structure (assessed by denaturing gradient gel electrophoresis profiles) and function (assessed by Catabolic Response Profile using different substrates) were all significantly decreased. The acidifying effect of $E$. camaldulensis, the effect of high level of polyphenols and their impact on microbial communities and ecosystem functioning were discussed.
\end{abstract}

Keywords: eucalyptus, allelopathy, microbial diversity, catabolic diversity, enzyme activities 


\section{Introduction}

Plantations of fast-growing trees have been extended in Sahelian zones because of their ecological plasticity (Bernhard-Reversat and Loumeto, 2002). Expansion of Eucalyptus plantations has been the focus of several studies throughout the world, usually related to their economic importance. Eucalyptus is commonly used in reforestation because of its high cellulose production, high fiber quality, and resistance to environmental stresses and diseases (Turnbull, 1999; Berthelot et al., 2000; Cossalter and Pye-Smith, 2003). Several environmental impact studies on carbon flux, water balance and soil fertility have been conducted in industrial plantations in Congo and Brazil, in response to criticisms by opponents of Eucalyptus plantations (Bouillet et al., 1997; Bouillet and Bernhard-Reversat, 2001; Laclau et al., 2004). It has been shown that, in addition to their acidifying affects (Cannell, 1999; Rhoades and Binkley, 1996; Farley et al., 2008), exotic species have mineral and water needs significantly higher than native species (Benhard-Reversat, 1987; Laclau, et al., 2005). It is noteworthy that, despite being very informative, these studies did not take into account the microbiological characteristics and more specifically, microbial genetic and functional diversities in soils with Eucalyptus plantations.

In Senegal, many Eucalyptus plantations have been planted in different regions by the Senegalese Institute of Agricultural Research (DRFP/ISRA), in its tree improvement program. The extent of studies conducted in the past encouraged researchers to select $E$. camaldulensis as the species which is best adapted to soil and climatic conditions of the experimental stations throughout Senegal (Giffard, 1969; Hamel, 1981). But little attention has been paid to diversity and functionalities of microbial communities under Eucalyptus soil. Yet, microbial communities are the most sensitive and most affected by the replacement of native vegetation by exogenous plant cover ( $\mathrm{Yu}, 2005)$.

In fact, soil microorganisms are extremely diverse and play an important role in ecosystems. In soils, they mediate nutrient cycling, organic matter decomposition, soil aggregate formation, soil carbon storage (Zinn et al., 2002), and have an impact on composition of plant communities (Hooper et al., 2000; Wardle, 2002) and plant disease prevention and bio-control (Kennedy, 1998; Biró et al., 2000; Artursonn, et al., 2006). The microbial community composition and functioning can be influenced by exudates from roots and litter quality and quantity. According to Powlson et al. (1987), soil microbial biomass measurement can give an early indication of soil health before changes in total organic $\mathrm{C}$ and $\mathrm{N}$ can be reliably detected. In order to draw meaningful conclusions we assessed a set of parameters (microbial biomass, enzyme activities, functional diversity, etc.) as early indicators of stress and disturbance (Dick et al., 1996; Nannipieri and Eldor, 2009).

So far in Senegal, studies on impact of Eucalyptus plantations on soil health were limited to greenhouse or site scale. This is the first large scale study conducted in Eucalyptus plantations in Senegal (across several sites and different ages of plantations).

The aim of this study was to determine the impact of E. camaldulensis plantations on microbial genetic and functional diversities, including microbial biomass. Importantly, studies have indicated that Eucalyptus leaves contain toxic organic compounds (high quantities of lignin, polyphenol compounds, allelochemicals, etc.) which may have a deleterious impact on soil microorganisms. We hypothesized that E. camaldulensis will lead to changes in soil chemical and microbiological properties that will ultimately limit the catabolic capabilities of native microbial communities. 


\section{Materials and Methods}

\section{Study sites and soil sampling}

The sampling sites were selected in 6-, 11- and 26-year-old Eucalyptus plantations considered respectively as young, intermediate and old. Young plantations correspond to Sinthiou, Kolda and Nioro. As shown on the map (Fig 1), Nioro is located in southwest of Senegal $\left(15^{\circ} 19 \mathrm{~N} ; 04^{\circ} 17 \mathrm{~W}\right)$, Sinthiou is in the North $\left(17^{\circ} 15 \mathrm{~N} ; 06^{\circ} 82 \mathrm{~W}\right.$ while Kolda is in South Senegal $\left(14^{\circ} 27 \mathrm{~N} ; 05^{\circ} 77 \mathrm{~W}\right)$. Intermediate plantation corresponds to Matam (North) collection $\left(17^{\circ} 30 \mathrm{~N} ; 06^{\circ} 87 \mathrm{~W}\right)$ and old plantations correspond to Lompoul $\left(17^{\circ} 07 \mathrm{~N}\right.$; $\left.03^{\circ} 69 \mathrm{~W}\right)$ and Tamba sites $\left(15^{\circ} 23 \mathrm{~N}\right.$; $\left.06^{\circ} 40 \mathrm{~W}\right)$ respectively in the center and in the North of Senegal. The rainfall distribution patterns across Senegal are presented in Fig 1. From each site, five soil samples were collected under five Eucalyptus trees from 0 to $30 \mathrm{~cm}$ soil depth and mixed to form one composite sample (noted SC). And three composite samples were collected per plantation. This soil was considered to be influenced by Eucalyptus. At each site, three other composite soil sample was formed with soil collected in areas free of Eucalyptus and located at a distance of $30 \mathrm{~m}$ from Eucalyptus plantings (control sample or HC). These soil samples were supposedly uninfluenced by Eucalyptus.

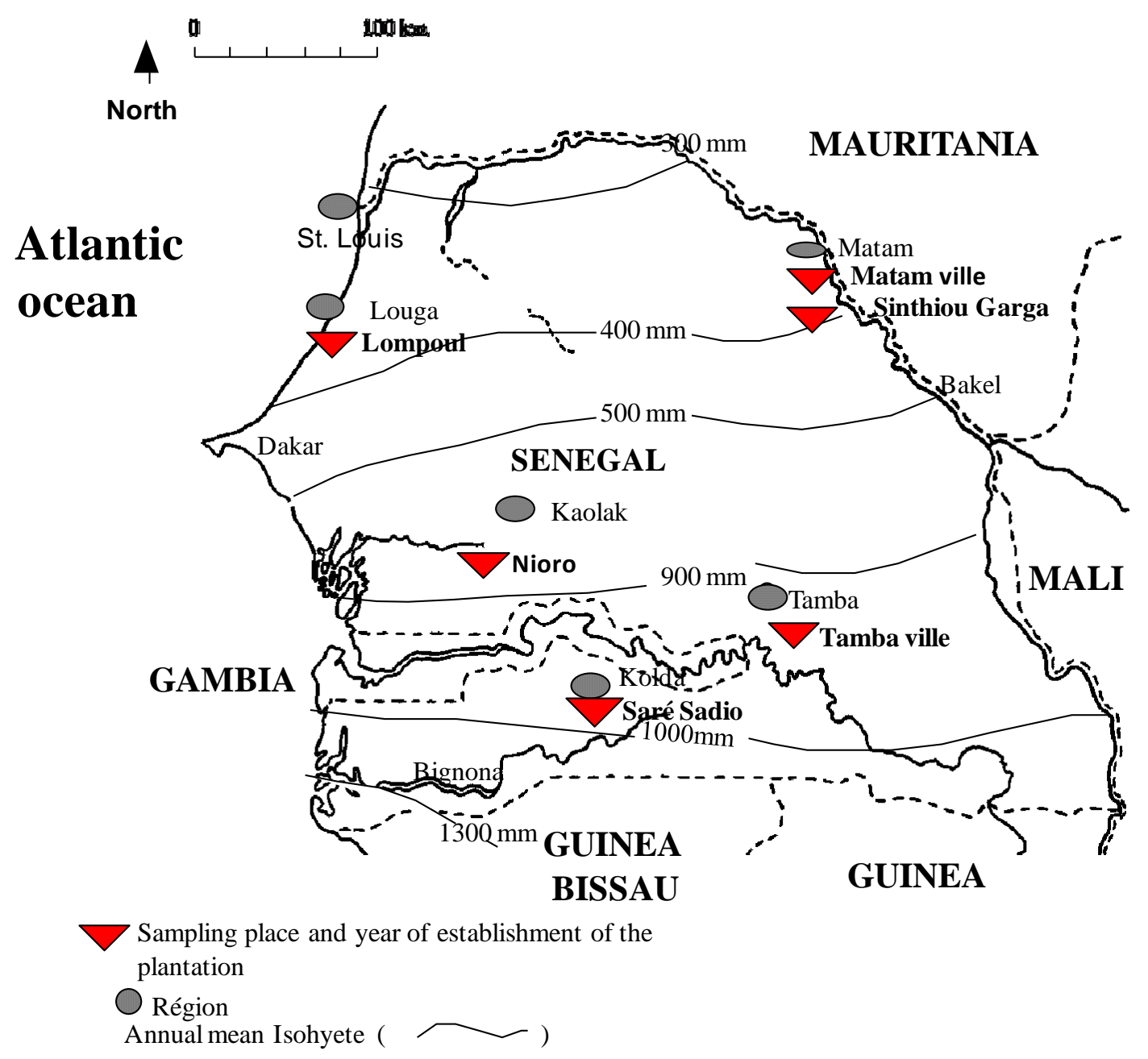

Figure 1. Study site and the exact locations of sampling 


\section{Soil analyses}

\section{Chemical analysis of soil}

All soil samples were characterized by measuring $\mathrm{pH}$, total soil $\mathrm{C}$ and $\mathrm{N}$ after dry combustion in Elemental Analyzer (LECO Corporation, St. Joseph, MI, USA). Total and available P were analyzed by Olsen-Dabin method (Olsen et al., 1954; Aubert, 1978). Analyses were performed at LAMA (Laboratoire des Moyens Analytiques IRD/ISRA, laboratory certified by International Organization for Standardization ISO 9001 version 2008).

\section{Total polyphenol content}

The method described by Macheix et al. (1990) was adapted to determine total polyphenol content. One gram of each soil sample was shaken in $20 \mathrm{ml}$ cold methanol $(80 \% \mathrm{v} / \mathrm{v})$ during 15 minutes and the mixture was centrifuged for 3 minutes at $5000 \mathrm{rpm}$ at $4^{\circ} \mathrm{C}$. This step was repeated three times before the supernatants were evaporated to remove methanol. A solution of ammonium sulphate $(40 \% \mathrm{v} / \mathrm{v})$ was added to the aqueous extract in order to increase the ionic strength of the solution and metaphosphoric acid solution $20 \%(1 / 10 \mathrm{v} / \mathrm{v})$ was also added to prevent oxidation of phenolic compounds.

This phase was followed by depigmentation and defatting of aqueous extract with petroleum ether ( $\mathrm{v} / 2)$. The extract was purified by ethylene acetate $(\mathrm{v} / \mathrm{v})$ and evaporated to dryness at $35^{\circ} \mathrm{C}$ with a rotary evaporator and the residue was recovered in $2 \mathrm{ml}$ of pure methanol. Extraction was repeated 3 times for each soil sample.

Total polyphenol content was determined by spectrophotometry, using (+/-)catechin as standard range (Singleton and Rossi, 1965). Briefly, $50 \mu 1$ of the diluted sample extract was mixed with $1.35 \mathrm{ml}$ of distilled water and $200 \mu 1$ of FolinCiocalteu's reagent. Then, $400 \mu \mathrm{l}$ of sodium carbonate solution $(20 \% \mathrm{w} / \mathrm{v})$ was added. The test tubes were placed in a water bath for 20 minutes at $40^{\circ} \mathrm{C}$ before absorbance was measured at $760 \mathrm{~nm}$. The concentration of polyphenols in samples was derived from a standard curve (+/-) - catechin ranging from 5 to $30 \mu \mathrm{g} \mathrm{ml}^{-1}$.

\section{Total microbial biomass}

Microbial biomass (MB) was estimated using substrate induced respiration method (Anderson and Domsch, 1978). The soil microbial content was estimated from the maximum rate of glucose-induced respiration by applying the formula below:

$$
\mathrm{x}=40.04 \mathrm{y}+0.37
$$

where $\mathrm{y}=$ the maximum initial rate of respiration (in $\mathrm{ml} \mathrm{CO}_{2} 100 \mathrm{~g} \mathrm{soil}^{-1} \mathrm{~h}^{-1}$ ), and $\mathrm{x}$ $=\mathrm{mg}$ microbial-C $100 \mathrm{~g} \mathrm{soil}^{-1}$. Microbial $\mathrm{CO}_{2}$ respiration was determined by direct injection into a micro GC Analytical Instruments SRA (MTI P200, Microsensor Technology Inc., Fremont, CA.) equipped with a TCD detector using helium as the carrier gas. 


\section{Soil enzyme activity}

Acid and alkaline phosphatases and dehydogenase activity were determined on Eucalyptus rhizospheric soils and compared to control soil samples.

These phosphatase activities (alkaline and acid) were determined on $0.5 \mathrm{~g}$ of dry soil according to the method of Eivazi and Tabatabai (1977).

For each soil sample, soil were mixed with $400 \mu \mathrm{L}$ of modified universal sterile buffer (at $\mathrm{pH} 5.8$ for acid phosphatase and $\mathrm{pH} 11$ for alkaline phosphatase) and $100 \mu \mathrm{l}$ of pnitrophenyl phosphate solution (pNPP) before being incubated for 1 hour at $37^{\circ} \mathrm{C}$ on a rotary shaker. The reaction was stopped by adding $100 \mu \mathrm{l}$ of $\mathrm{CaCl}_{2}$ and $400 \mu \mathrm{l}$ of $\mathrm{NaOH}$, and the soil suspensions were centrifuged at $12000 \mathrm{rpm}$ for 10 minutes. Then, the absorbance readings were taken at $400 \mathrm{~nm}$. Analyses were conducted in triplicate and one non-substrate control and results are expressed as $\mu \mathrm{g}$ p-nitrophenol release. $\mathrm{g}^{-1} \mathrm{~h}^{-1}$ at $37^{\circ} \mathrm{C}$.

Dehydrogenase activity was assayed by a method from Casida et al. (1964) with few modifications. One g soil sample was mixed with $1 \mathrm{ml}$ of tris buffer, $1 \mathrm{ml} 4 \%(\mathrm{w} / \mathrm{v})$ of 2, 3, 5-triphenyltetrazolium chloride (TTC) and incubated for $24 \mathrm{~h}$ at $37{ }^{\circ} \mathrm{C}$. Dehydrogenase enzymes convert TTC to 2, 3, 5-triphenylformazan (TPF). $1 \mathrm{ml}$ of $4 \%$ TTC and $2.5 \mathrm{ml}$ of $\mathrm{H}_{2} \mathrm{O}$ were added to each tube before they were inverted a few times and incubated at $37^{\circ} \mathrm{C}$ for 24 hours. A control sample contained all the chemicals mentioned above except the TTC. Each soil sample was extracted with $5 \mathrm{ml}$ of acetone after incubation. The extract was centrifuged and the optical density (O.D.) of the supernatant was read at $546 \mathrm{~nm}$ in a spectrophotometer. Results were expressed as $\mu \mathrm{g}$ TPF $g^{-1} h^{-1}$.

\section{Catabolic Response Profiles}

The functional diversity of heterotrophic microbial communities was determined by measuring the patterns of in situ catabolic potential (ISCP, CRP). The ISCP is a physiological approach developed by Degens and Harris (1997). This method is based in a serial measure of $\mathrm{CO}_{2}$ production in a short term after adding different organic substrates. Thirty three substrates (33) belonging to various chemical groups: eleven amino acids (arginine, aspargine, L-cysteine, L-glutamic acid, L-hisdidine, L-serine, Ltyrosine, L-lysine, L-leucine, L-proline, L-glutamine), six carbohydrates (amidon, Dmannose, D-glucose, sucrose, threalose, maltose), twelve organic acids (gallic acid, ascorbic acid, citric acid, fumaric acid, malic acid, quinic acid, succinic acid, tartaric acid, malonic acid, $\alpha$-ketoglutaric acid, oxalic acid, panthothenic acid), one amine (Dglucosamine) and three alcohols (meso inositol, sorbitol, mannitol) were used on three replicate soil samples to evaluate soil microflora capacity to catabolize different $\mathrm{C}$ sources. Each substrate was added at $0.5 \mathrm{mg} \mathrm{C.g}$ soil $^{-1}$ concentration in $70 \%$ waterholding capacity of each soil in vacutainers bottles. Solutions were adjusted to $\mathrm{pH} 5.8$ 6.2 before addition to soil, using $\mathrm{NaOH}$ or $\mathrm{HCl}$ to increase or decrease the $\mathrm{pH}$ at the time of preparation in order to avoid any substrate-pH effects on microbial communities. A control without substrate, with only water added was included. Bottles were incubated for $2 \mathrm{~h}$ at ambient temperature $\left(25^{\circ} \mathrm{C}\right)$ and $\mathrm{CO}_{2}$ fluxes from the soils were measured by $\mu \mathrm{CPG}$ (Analytical Instruments SRA (MTI P200, Microsensor Technology Inc., Fremont, CA.) equipped with a TCD detector using Helium as the carrier gas). Results were expressed as $\mu \mathrm{gCO}_{2} \mathrm{~g}^{-1}$ soil $^{-1}$. 
Catabolic evenness (E), defined as the variability in substrate utilization, was evaluated by $\mathrm{E}=1 / \Sigma p_{i}{ }^{2}$ where $p i=$ ratio of respiration response on the $i^{\text {th }}$ substrate to the sum of the respiration responses on all substrates.

\section{Genetic diversity}

Whole-community DNA was directly extracted from $0.5 \mathrm{~g}$ of sample using a beadbeating method (Fast DNA SPIN Kit for soil, Bio 101 Inc., USA) following manufacturer's instructions.

The 16S rDNA (V3 sequence) fragments of the bacterial soil community were amplified with 338f-GC and 518r primers (Muyzer et al., 1993). The PCR and DGGE were performed as described by Fall et al. (2004). The number of bands and their positions on the DGGE gel were analyzed using the Bio-Profil Biogene program (Vilber Lourmat) and dendrograms were created based on Dice coefficient of similarity.

The species richness on DGGE gels (R) was calculated as the mean number of bands present (Vivas et al., 2008, 2009). The structural diversity of the microbial community was examined by the Shannon index of general diversity and Simpson index of dominance D (Simpson, 1949). For these analyses, each band was presumed to represent the ability of that bacterial species to be amplified (Vivas et al., 2008, 2009). The intensity of the bands was reflected as peak heights in the densitometric curve. The Shannon H' and Simpson D indexes were calculated from the following equations: $\mathrm{H}^{\prime}=$ $-\Sigma\left(P_{i} \log P_{i}^{2}\right) D=\Sigma P_{i}^{2} ; P_{\mathrm{i}}=\mathrm{ni} / \mathrm{N} ; \mathrm{ni}=$ height of peak and $\mathrm{N}=$ sum of all peak heights in the curve.

\section{Statistical analyses}

Co-inertia analysis (CIA) was used to analyze the relationship between chemical and microbial properties and sample type in different sites. Additionally, Student-Newman Keuls test was done to separate the means when the ANOVA revealed significant differences at 5\% level. The relationship of Karl Pearson is used to correlate the different variables measured in this experiment. Between-group analysis (BGA) was used for the SIR responses because number of cases is lower than the number of variables (12 soil samples and 33 SIR substrates). The free ADE4 software (Thioulouse et al., 1997) was used to perform BGA computations.

\section{Results}

ACP analysis showed clear separation between plantations according to age. Young and old plantations (young SC and old SC) correspond to axis 1 (38.44\% of the total contribution rate) and were associated with low $\mathrm{pH}$, low $\mathrm{MB}$, and low diversity index (Fig. 2, Table 1). While intermediate plantation (med SC) was associated to axis 2 ( $31.41 \%$ of the total contribution rate) and is mainly characterized by very high levels of phenols and phosphatase (Fig. 2; Table 1).

Table 1. Change in chemical and biological variables according to plantation age

\begin{tabular}{lllllllll}
\hline & Desy & $\begin{array}{l}\text { Ac. } \\
\text { phos }\end{array}$ & $\begin{array}{l}\text { Al. } \\
\text { Phos }\end{array}$ & H & E & MB & Total poly & $\mathrm{pH}_{2} \mathrm{O}$ \\
\cline { 2 - 8 } med & $8,48 \mathrm{a}$ & $764,12 \mathrm{a}$ & $364,28 \mathrm{a}$ & $1,47 \mathrm{ab}$ & $28,81 \mathrm{ab}$ & $4276,14 \mathrm{a}$ & $18,1 \mathrm{a}$ & $6,67 \mathrm{a}$ \\
old & $6,91 \mathrm{~b}$ & $382,93 \mathrm{~b}$ & $95,99 \mathrm{~b}$ & $1,45 \mathrm{~b}$ & $30,83 \mathrm{a}$ & $1015,40 \mathrm{~b}$ & $6,44 \mathrm{~b}$ & $5,49 \mathrm{~b}$
\end{tabular}




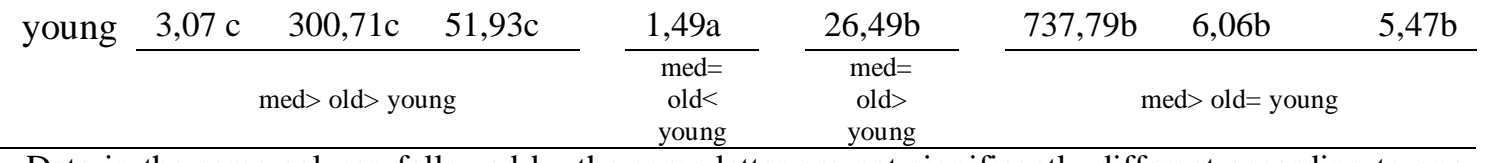

Data in the same column followed by the same letter are not significantly different according to oneway ANOVA ( $<$ 0.05). Abbreviations: Shannon $(\mathrm{H})$, Simpson (D), Species richness (R), total microbial biomass (MB); alkaline phosphatase (Al. phos), acid phosphatase (Ac. Phos), dehydrogenase (Desy), total polyphenol content (Total poly)
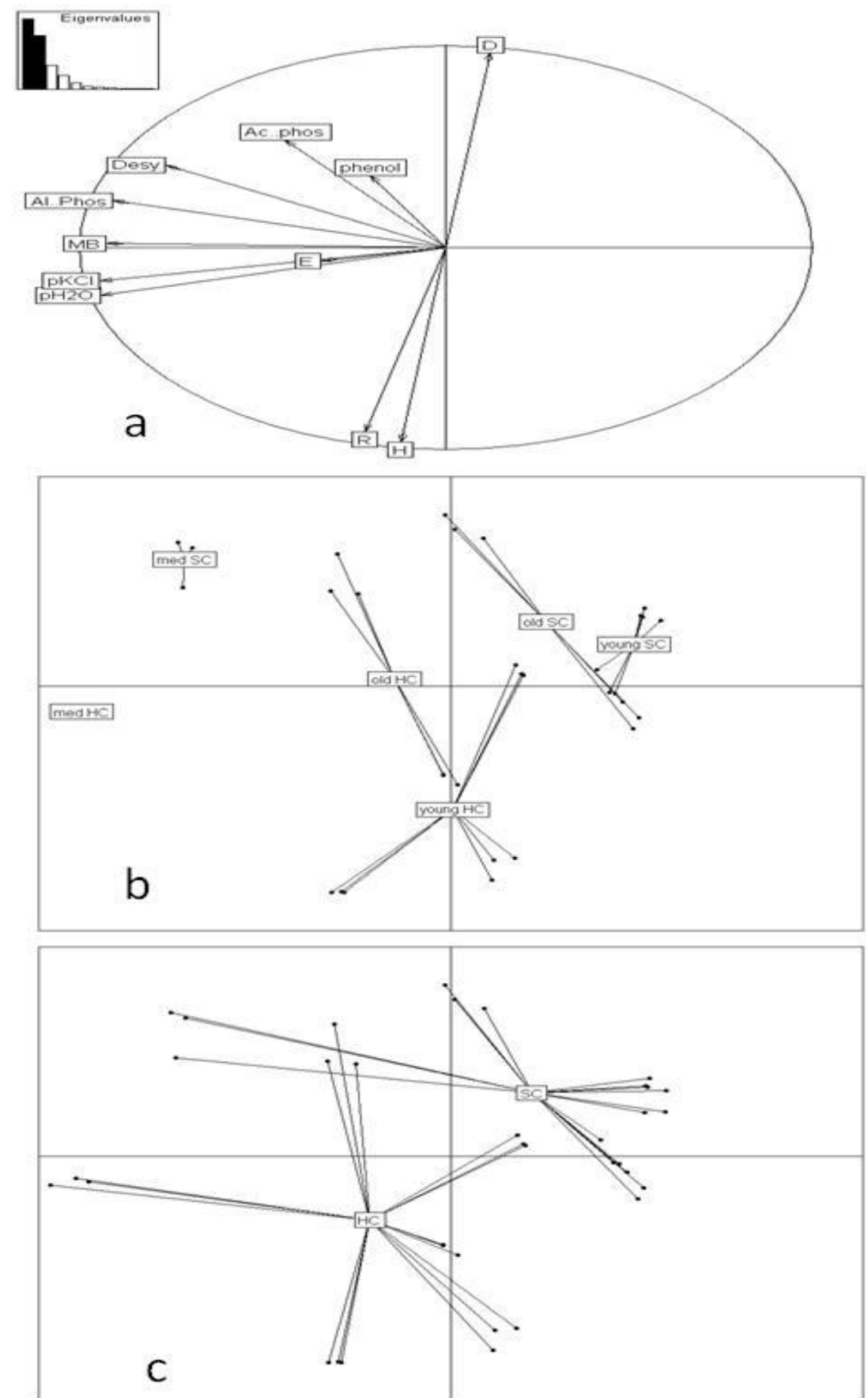

Figure 2. Principal Component Analysis showing the relationship between the chemical and microbiological properties $(a)$ of Eucalyptus plantations based on age $(b)$ and sample type (HCvsSC) (c); SC: under Eucalyptus samples and HC: control samples 
Canonical correlation analysis (Fig. 2c) showed a sharp contrast between HC and SC samples on basis of different variables measured. Irrespective of the age, the control samples (HC) were associated with low total polyphenol, high $\mathrm{pH}$, high microbial biomass, high alkaline phosphatase, high dehydogenase and greater diversity index $\left(\mathrm{H}^{\prime}\right.$ and R). ANOVA between separate means is presented in Table 2 and Table 3.

Differences in $\mathrm{pH}$ between $\mathrm{HC}$ and SC were significantly lower in soils under Eucalyptus compared to soils without Eucalyptus in all age groups (Table 2). However, this acidity was not associated with age of plantation. For example, old plantation of Lompoul and young plantation of Nioro showed the same $\Delta_{\mathrm{pH}}$ (HC-SC) (1.2 and 1.3 respectively). Also, acidification effect on microbial activities was different. In the old plantation of Lompoul, microbial biomass was not changed but its activity and diversity were strongly modified (dehydogenase, alkaline phosphatase, E and H'). In contrast, in the old planting of Tamba, BM was significantly reduced as well microbial activities although, catabolic diversity remained intact. Within the group of young plantations, the effect of planting Eucalyptus on biological variables appeared similar through reduced BM, enzymatic activity and microbial diversity. ANOVA analysis showed that the difference in polyphenol content between HC and SC were significantly higher in SC irrespective of the age group (Fig. 2).

\section{Functional diversity}

In terms of functional diversity in the different age groups, Acid phosphatase activity did not present any significant difference between HC under SC (except in the intermediate plantation at Matam). While alkaline phosphatase activity was significantly highest in Eucalyptus-free soil (HC) (Table 2, Fig. $2 a$ and 2c). In most of the case, microbial biomass and dehydrogenase activity showed the same trend in different age groups.

The ISCP patterns highlight a strong site effect mainly due to the opposition of Matam/Lompoul, Sinthiou and Kolda. The soil of Matam was characterized by high levels of $\mathrm{P}, \mathrm{N}$, and high $\mathrm{pH}$ compared to other samples (Table 4 and Fig. 3a).

If the site effect is removed, the difference between $\mathrm{HC}$ and SC is very clear (Fig. $3 a$ ). All groups of substrates induced significantly higher $\mathrm{CO}_{2}$ emissions in control soils (HC) compared to SC samples except for the old plantation of Lompoul (Fig. 3a). The higher catabolic evenness $\mathrm{E}$ found in $\mathrm{HC}$ samples (Table 2) confirmed the functional difference. This difference in ISCP response between HC and SC samples was more marked in younger plantations (Sinthiou Garba, Nioro and Kolda sites) (data not shown) than old and intermediate plantations. However the permutation test of BGA between HC/SC was not significant (Fig. $3 b$ ).

\section{Genetic diversity}

Table 3 showed the effect of Eucalyptus plantations on bacterial communities. Importantly, the Shannon index showed that the microbial community diversity, characterized by the number and intensity of DGGE bands, was significantly higher in sites free of Eucalyptus (HC) compared to Eucalyptus-covered sites (SC) for each couple of soil samples. Specific richness (R) showed the same trend although the differences were not significant in all site. Contrarily, Simpson's dominance (D) was higher in SC samples compared to the controls for all groups (old, young and med). Dominance measures the relative abundances and decreases progressively as the relative abundance of microbes become more equitable. The maximum dominance (value 1) corresponds to a site that contains one dominant species. 
Table 2. pH and biological characteristic of soils (means of three replicates)

\begin{tabular}{|c|c|c|c|c|c|c|c|c|c|c|c|c|}
\hline & \multicolumn{4}{|c|}{ old } & \multirow{2}{*}{\multicolumn{2}{|c|}{$\frac{\text { med }}{\text { Matam }}$}} & \multicolumn{6}{|c|}{ young } \\
\hline & \multicolumn{2}{|c|}{ Lompoul } & \multicolumn{2}{|l|}{ Tamba } & & & \multicolumn{2}{|c|}{ Sinthiou } & \multicolumn{2}{|l|}{ Kolda } & \multicolumn{2}{|l|}{ Nioro } \\
\hline & $\mathrm{HC}$ & $\mathrm{SC}$ & $\mathrm{HC}$ & $\mathrm{SC}$ & $\mathrm{HC}$ & SC & $\mathrm{HC}$ & $\mathrm{SC}$ & $\mathrm{HC}$ & $\mathrm{SC}$ & $\mathrm{HC}$ & $\mathrm{SC}$ \\
\hline $\mathrm{pH}_{\mathrm{H} 2 \mathrm{O}}$ & $6.34 \mathrm{a}$ & $5.12 \mathrm{c}$ & $6.41 \mathrm{~b}$ & $5.87 \mathrm{a}$ & $7.44 \mathrm{a}$ & $6.87 \mathrm{~b}$ & $6.17 \mathrm{~b}$ & $5.35 \mathrm{e}$ & $5.28 \mathrm{c}$ & $5.55 \mathrm{~d}$ & $6.83 \mathrm{a}$ & $5.53 \mathrm{~d}$ \\
\hline $\mathrm{pH}_{\mathrm{KCl}}$ & $5.37 \mathrm{~b}$ & $4.46 \mathrm{c}$ & $5.62 \mathrm{~b}$ & $5.30 \mathrm{a}$ & $6.86 \mathrm{a}$ & $6.00 \mathrm{~b}$ & $5.04 \mathrm{c}$ & $4.28 \mathrm{e}$ & $5.28 \mathrm{~b}$ & $4.95 \mathrm{c}$ & $6.32 \mathrm{a}$ & $4.66 \mathrm{~d}$ \\
\hline $\begin{array}{l}\text { Total poly. } \\
m g . \text { soil }^{-1}\end{array}$ & $4.81 \mathrm{bc}$ & $10.58 \mathrm{a}$ & $2.37 \mathrm{c}$ & $6.52 b$ & $7.78 \mathrm{~b}$ & $28.41 \mathrm{a}$ & $2.78 \mathrm{c}$ & $17.09 \mathrm{a}$ & $0.617 \mathrm{c}$ & $10.40 \mathrm{~b}$ & $3.10 \mathrm{c}$ & $4.67 \mathrm{c}$ \\
\hline $\begin{array}{l}\mathrm{MB}(\mu g C- \\
\mathrm{CO} 2 \cdot 100 g \\
\left.\text { soil }^{-1} \cdot h^{-1}\right)\end{array}$ & $49,16 \mathrm{c}$ & $49,07 \mathrm{c}$ & $187,36 \mathrm{a}$ & $120,57 \mathrm{~b}$ & $541,25 \mathrm{a}$ & $313,98 \mathrm{~b}$ & $58,67 \mathrm{~b}$ & $21,51 \mathrm{~d}$ & $45,28 \mathrm{~b}$ & $30,13 \mathrm{c}$ & $242,86 \mathrm{a}$ & $44,23 \mathrm{~b}$ \\
\hline $\begin{array}{l}\text { Simpson- } \\
\text { Yule index } \\
(E)\end{array}$ & $30.10 \mathrm{~b}$ & $28.73 \mathrm{c}$ & $32.2 \mathrm{a}$ & $32.3 \mathrm{a}$ & $30.20 \mathrm{a}$ & $27,0 \mathrm{~b}$ & $31.70 \mathrm{a}$ & $30,0 \mathrm{~b}$ & $24.1 \mathrm{~d}$ & $18.2 \mathrm{e}$ & $29.6 \mathrm{~b}$ & $25.2 \mathrm{c}$ \\
\hline $\begin{array}{l}\text { Ac. phos. } \\
(\mu g \text { pNPP g } \\
\left.. h^{-1}\right)\end{array}$ & $206.1 \mathrm{c}$ & $346.7 \mathrm{~cd}$ & $415.7 \mathrm{ab}$ & $509.2 \mathrm{a}$ & $333.6 \mathrm{~b}$ & $1194.6 \mathrm{a}$ & $262.5 \mathrm{~b}$ & $264.5 \mathrm{~b}$ & $370.7 \mathrm{a}$ & $429.0 \mathrm{a}$ & $221.2 \mathrm{~b}$ & $256.1 \mathrm{~b}$ \\
\hline $\begin{array}{l}\text { Al. phos }(\mu g \\
\left.\operatorname{pNPP}^{-1} \cdot h^{-1}\right)\end{array}$ & $89.0 \mathrm{~b}$ & $25.0 \mathrm{c}$ & $188.0 \mathrm{a}$ & $81.7 \mathrm{~b}$ & 388.8 a & $339.6 \mathrm{~b}$ & $73.8 \mathrm{~b}$ & $6.4 \mathrm{e}$ & $119.0 \mathrm{a}$ & $33.9 \mathrm{~d}$ & $54.9 \mathrm{c}$ & $23.4 \mathrm{~d}$ \\
\hline $\begin{array}{l}\text { Desy }(\mu \mathrm{g} \\
\left.\text { TPF } \mathrm{g}^{-1} \cdot \mathrm{h}^{-1}\right)\end{array}$ & $6.51 \mathrm{~b}$ & $1.22 \mathrm{c}$ & $11.02 \mathrm{a}$ & $8.56 \mathrm{~b}$ & $8.765 \mathrm{a}$ & $8.194 \mathrm{a}$ & $2.11 \mathrm{~b}$ & $1.24 \mathrm{c}$ & $5.09 \mathrm{a}$ & $2.978 \mathrm{~b}$ & $4.64 \mathrm{a}$ & $2.392 \mathrm{~b}$ \\
\hline
\end{tabular}

Data in the same line followed by the same letter in each age range are not significantly different according to one-way ANOVA (P < 0.05$)$. HC and SC as in Figure 2. MB: total microbial biomass, Al. phos: alkaline phosphatase, Ac. Phos: acid phosphatase, Desy: Dehydrogenase. 
Table 3. Shannon (H), Simpson (D), Species richness $(R)$ diversity indexes values for DGGE profiles under and out cover of E. camaldulensis

\begin{tabular}{|c|c|c|c|c|c|c|c|c|c|c|c|c|}
\hline Age & & old & & & med & & & & young & & & \\
\hline & LHC & LSC & THC & TSC & MHC & MSC & SHC & SSC & KHC & KSC & NHC & NSC \\
\hline $\mathrm{H}$ & $1,523 \mathrm{a}$ & $1,480 \mathrm{~b}$ & $1,426 \mathrm{c}$ & $1,397 \mathrm{~d}$ & $1.484 \mathrm{a}$ & $1.460 \mathrm{a}$ & $1.574 \mathrm{~b}$ & $1.452 \mathrm{e}$ & $1,470 \mathrm{~d}$ & $1,486 \mathrm{c}$ & $1,586 \mathrm{a}$ & $1,426 \mathrm{f}$ \\
\hline $\mathrm{D}$ & $0,031 \mathrm{e}$ & $0,034 \mathrm{~d}$ & $0,03 \mathrm{a}$ & $0,04 \mathrm{a}$ & $0,034 \mathrm{~b}$ & $0,04 \mathrm{a}$ & $0,03 \mathrm{~d}$ & $0,04 \mathrm{a}$ & $0,035 \mathrm{~b}$ & $0,038 \mathrm{c}$ & $0,04 \mathrm{~d}$ & $0,03 \mathrm{a}$ \\
\hline $\mathrm{R}$ & $37 \mathrm{~b}$ & $36 \mathrm{~b}$ & $31 \mathrm{a}$ & $27 \mathrm{c}$ & $35,6 \mathrm{a}$ & $34,6 \mathrm{a}$ & $40 \mathrm{a}$ & $40 \mathrm{a}$ & $33 \mathrm{~b}$ & $32,6 \mathrm{~b}$ & $41 \mathrm{a}$ & $29 \mathrm{c}$ \\
\hline
\end{tabular}

Data in the same line followed by the same letter in each age range are not significantly different according to one-way ANOVA (P < 0.05). Abbreviations for sampling site L: Lompoul, M: Matam, S: Sinthiou, T: Tamba, K: Kolda, and N: Nioro; HC : control samples and SC : Under Eucalyptus samples. 
Table 4. Soil chemical characteristics

\begin{tabular}{|c|c|c|c|c|c|c|c|c|c|c|c|c|}
\hline \multirow{3}{*}{$\begin{array}{l}\text { age } \\
\text { site } \\
\text { sample }\end{array}$} & \multicolumn{4}{|c|}{ old } & \multicolumn{2}{|c|}{ med } & \multicolumn{6}{|c|}{ young } \\
\hline & \multicolumn{2}{|c|}{ Lompoul } & \multicolumn{2}{|c|}{ Tamba } & \multicolumn{2}{|c|}{ Matam } & \multicolumn{2}{|c|}{ Sinthiou } & \multicolumn{2}{|c|}{ Kolda } & \multicolumn{2}{|c|}{ Nioro } \\
\hline & $\mathrm{HC}$ & $\mathrm{SC}$ & $\mathrm{HC}$ & $\mathrm{SC}$ & $\mathrm{HC}$ & $\mathrm{SC}$ & $\mathrm{HC}$ & $\mathrm{SC}$ & $\mathrm{HC}$ & $\mathrm{SC}$ & $\mathrm{HC}$ & $\mathrm{SC}$ \\
\hline $\mathrm{N}$ total $(\%)$ & 0.028 & 0.056 & 0.069 & 0.056 & 0.093 & 0.062 & 0.024 & 0.022 & 0.045 & 0.049 & 0.050 & 0.044 \\
\hline $\begin{array}{l}\text { Carbone } \\
\text { total }(\%)\end{array}$ & 0,295 & 0,688 & 0.992 & 0.807 & 0,95 & 0,699 & 0,24 & 0,224 & 0.599 & 0.671 & 0,629 & 0,54 \\
\hline $\begin{array}{l}\text { P. total } \\
(\mathrm{mg} / \mathrm{kg})\end{array}$ & 28 & 44 & 82 & 58 & 351 & 237 & 70 & 48 & 49 & 53 & 98 & 56 \\
\hline $\begin{array}{l}\text { P. available } \\
(\mathrm{mg} / \mathrm{kg})\end{array}$ & 3.49 & 11.35 & 6.11 & 8.73 & 141.40 & 47.13 & 4.36 & 6.11 & 3.93 & 4.80 & 20.08 & 9.16 \\
\hline
\end{tabular}

HC: control samples, SC: Under Eucalyptus samples 

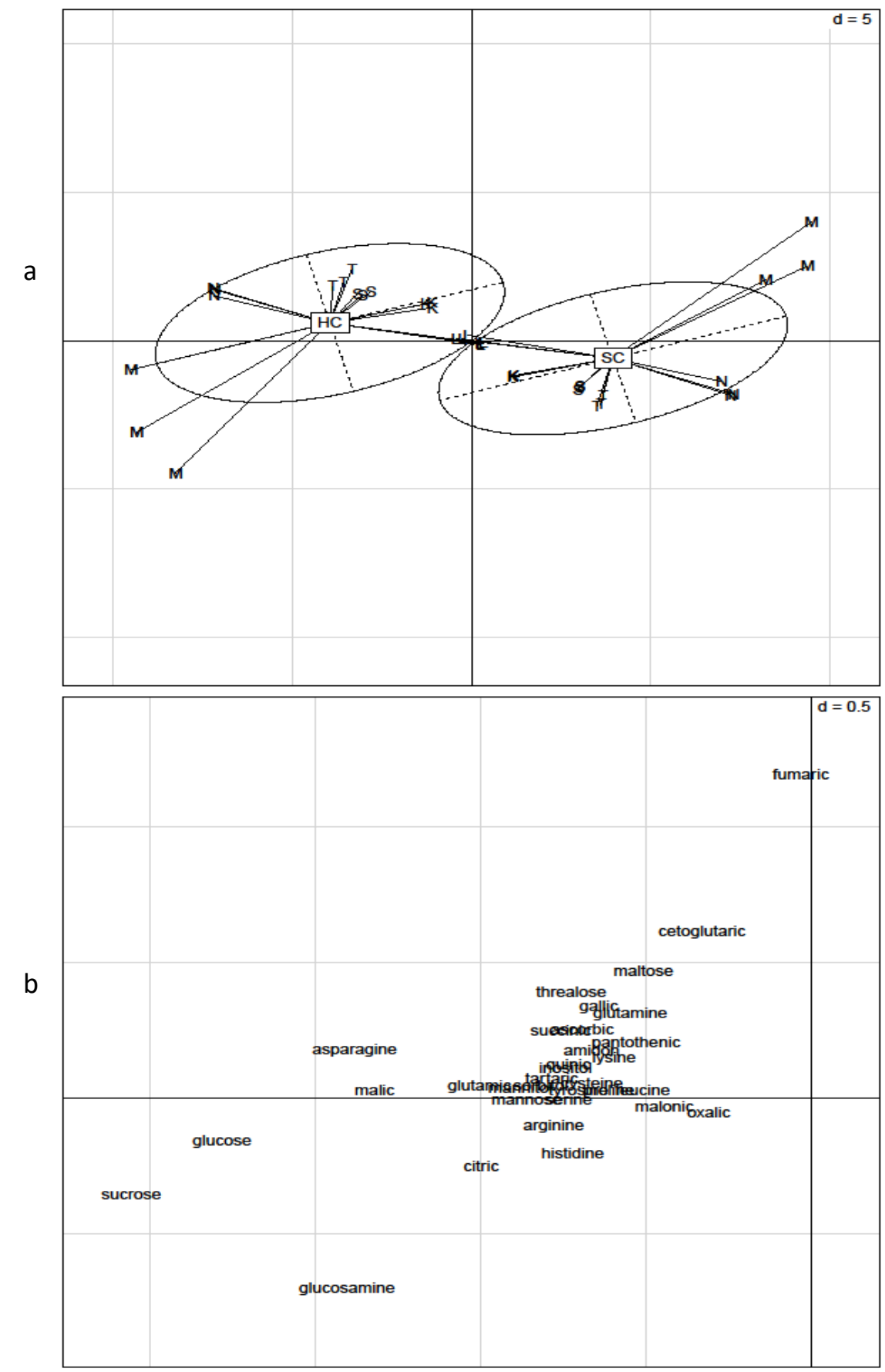

Figure 3. Between-group analysis (BGA) of in situ catabolic potential (ISCP) responses of soils under Eucalyptus compared with control soils. M: Matam, N: Nioro, L: Lompoul, S: Sinthiou Garba, K: Kolda, T: Tamba, HC : control samples and SC: Under Eucalyptus samples. a) Factor map of subtracts b) Factor map of SIR responses of soils.

Comparison of the bacterial community from Eucalyptus sites and control displayed distinct profiles on the DGGE gel (Fig. 4). The UPGMA dendrograms revealed that the structures of the bacterial communities from the young plantations were similar (similarity coefficient between 70 and $85 \%$ ) to that from the old plantations (similarity coefficient 60\%) (Fig. $4 a$ and $4 b$ ). 

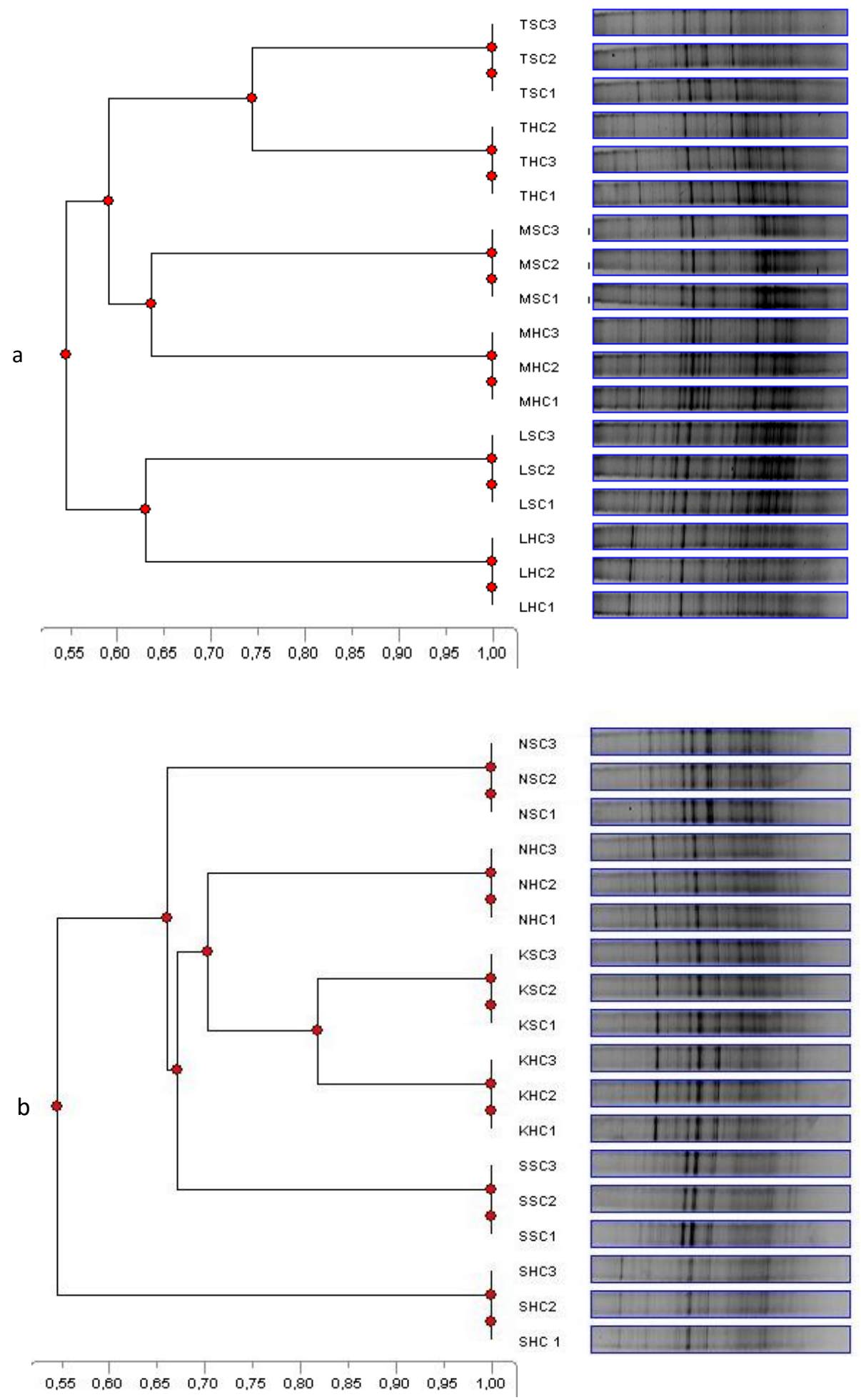

Figure 4. Dendrograms comparing the DGGE profiles of bacterial communities of soil sampling in $H C$ and $S C$ of E. camaldulensis plantations. $L, M, S, T, K, N ; H C$ : and SC are the same as in figure 3. Number 1, 2 and 3 correspond to three replications of each sample 
There were positive and significant correlations between microbial biomass and soil $\mathrm{pH}$ $\left(\mathrm{R}^{2}=0.87, \mathrm{p}<0.05\right)$ and between $\mathrm{MB}$ and alkaline phosphatase $\left(\mathrm{R}^{2}=0.88, \mathrm{p}<0.05\right)$. Also, positive correlations were found between soil total polyphenols content and acid phosphatase $\left(\mathrm{R}^{2}=0.65, \mathrm{p}<0.05\right)$. In contrast, significant negative correlation existed between catabolic evenness $(E)$ and total polyphenols content $\left(R^{2}=-0.618, p<0.05\right)$ (Table 5).

Table5. Correlation analysis between different variables measured in soils

\begin{tabular}{ccccccccc}
\hline Variables & Desy & Ac. phos. & Al. phos. & BM & pH & Total poly & E & H \\
\hline Déshy & $\mathbf{1}$ & & & & & & & \\
Ac. phos. & $\mathbf{0 , 4 7 7}$ & $\mathbf{1}$ & & & & & & \\
Al. phos. & $\mathbf{0 , 7 1 0}$ & 0,563 & $\mathbf{1}$ & & & & & \\
BM & $\mathbf{0 , 6 1 6}$ & 0,329 & $\mathbf{0 , 8 8 1}$ & $\mathbf{1}$ & & & & \\
pH & 0,393 & 0,202 & $\mathbf{0 , 7 9 2}$ & $\mathbf{0 , 8 6 8}$ & $\mathbf{1}$ & & & \\
poly & 0,208 & $\mathbf{0 , 6 5 4}$ & 0,377 & 0,342 & 0,054 & $\mathbf{1}$ & & \\
E & $-0,391$ & $\mathbf{- 0 , 8 2 4}$ & $\mathbf{0 , 6 9 7}$ & $-0,517$ & $-0,351$ & $\mathbf{- 0 , 6 1 8}$ & $\mathbf{1}$ & \\
H & $-0,301$ & $-0,171$ & $-0,278$ & $-0,083$ & 0,139 & 0,387 & $-0,061$ & $\mathbf{1}$ \\
\hline
\end{tabular}

Data values are different from 0 at significance level alpha $=0.05$. Abbreviations: Al. phos: alkaline phosphatase, Ac. phos: acid phosphatase, Desy: dehydrogenase, Total poly: total polyphenol content.

\section{Discussion}

Ours results showed that Eucalyptus modified soil properties by acidification and /or accumulation of antimicrobial compounds such as phenols. In intermediate plantations, high levels of polyphenol in soils resulted from litter accumulation because plants were at the shorter spacing (observed during the sampling). In old and young plantations acidification seemed most obvious. This acidification of soils under Eucalyptus could be caused by an accelerated extraction of basic cations by this fast-growing tree species, especially when extraction was not offset by fertilization. Indeed, a recent study reported an acidification of surface water due to soil depletion of cations when watershed and pasture were replaced by Eucalyptus plantations (Farley et al., 2008). Eucalyptus litter can also release many acidic compounds. According to Swift et al. (1979), decreasing $\mathrm{pH}$ in decaying litter was mainly due to the leaching of acidic material from the vacuoles. This acidifying effect was also reported by a set of studies conducted in Uruguayon an experimental site, ten years after the original vegetation was replaced by Eucalyptus plantation (Durán et al., 2001; Pérez Bidegain et al., 2001; Sicardi et al., 2004).

The consequences of these soil chemical modifications were the decline in microbial biomass, activity and diversity. In fact, the results obtained from the current study showed low microbial biomass and low catabolic capacity and low diversity (Shannon index and Evenness) under Eucalyptus soil. Similar results were obtained on Gmelina arborea Roxb and E. camaldulensis, two exotic species, by Sanon et al. (2006) 
and Kisa et al. (2007) respectively. These authors have shown that the exotic plants considerably alter soil properties by modifying both microbial community structure and functional diversity.

Ours results showed that acidification was not proportional to plantation age and its effect on microbial activity and biomass could be different even within the same age plantation. This difference could be related to soil texture which unfortunately was not measured in this study. But according to early studies, the soil of Matam (intermediate plantation) was a loam clay soil (Maymard, 1962) and was closed to a river, thus releasing few cations so little subject to acidification. Thus soil $\mathrm{pH}$ was highest $(\mathrm{pH}$ 6.87) in Matam. Whereas Nioro is a ferruginous soil (Pieri, 1969), Sinthiou and Lompoul are sandy (Maymard, 1962). These soils were more susceptible to acidification. Highest $\mathrm{pH}$ in Matam site compared to other plantations could explain highest enzymatic activities and microbial biomass.

Low microbial biomass and activity found under Eucalyptus plantation could be due to the toxic impact of harmful allelochemical compounds (including polyphenols) released from the Eucalyptus leaf litter. Negative correlation between catabolic Evenness (E) and total polyphenol contents suggests that phenols reduce microbial activity. Previously, Dellacassa et al. (1989) have reported antimicrobial activity of Eucalyptus leaf extract toward pure culture of soil bacteria. Consistently, our study also reported high rates of total polyphenols under Eucalyptus soil samples compared to adjacent soils. Polyphenols are known for their negative role in the mineralization process of organic matter either by complexing the protein nitrogen which would make it inaccessible to microorganisms or by the inhibition of microorganisms or enzymes responsible for the transformation of ammonium nitrate (Mangelot and Toutet, 1980; Duponnois et al., 2001; Diallo et al., 2006). The results of Blum and Shafer (1988) and Diallo et al. (2006) showed that the effect of phenols depend on the phenolic acid composition rather than concentration. According to these authors, acidic phenolic compounds have more negative effects alkaline than phenolic. The determination of soil phosphatase activities indicated less bacteria activity under Eucalyptus (evidenced by alkaline phosphatase) than in adjacent samplings. Furthermore, high fungal activity (evidenced by acid phosphatase) was found in samples under Eucalyptus. This change in soil microorganism activities could be related to changes in $\mathrm{pH}$ induced by $E$. camaldulensis. Similar results have previously been documented by Bradget et al. (1993) who showed that acidification increased abundance of fungal communities in the Boreal forest, whereas bacteria increase in alkaline soils. Our findings thus support previous observations suggesting that soil microbial communities composition is greatly controlled by $\mathrm{pH}$ as shown by the strong and positive correlation between $\mathrm{pH}$ and $\mathrm{MB}$.

Changes (acidifying effects and/or high polyphenol content) mediated by $E$. camaldulensis in soils can reduce catabolic groups and/or soil catabolic ability. Indeed, E. camaldulensis, by its root exudates and litter fall select microorganisms able to use its carbon residues and support its acidifying effect. Meyer (1994) and Kourtev et al. (2003) demonstrated that exotic species promote changes in functional groups within the microbiota. Similar results were reported by Saetre and Bååth (2000) and Yao et al. (2000) which showed that changes in the ratio of Gram-negative to Gram-positive bacteria were related to quality of organic matter in the soil under exotic species. Recent studies that have used BIOLOG (Yu et al., 2005), noted great modifications in catabolic activity forms of soil bacterial community with 31 carbon resources in soils treated by Eupatorium adenophorum (an exotic invasive species) root water extract. In our study, 
the combined effect of low $\mathrm{pH}$ and litter accumulation could explain the lack of herbaceous layer noted under E. camaldulensis.

\section{Conclusion}

The results showed that Eucalyptus cultivation negatively impacted on soils at all sites regardless of the age of the plantation. Intermediate plantation appeared to be characterized by high levels of phenols, while in young and old plantations $\mathrm{pH}$ effect was dominant. In both situations, this had a negative effect on microbial biomass, activity and diversity.

Among all the measured indicators, acidification, phosphatases activities and the accumulation of phenols were the most common observations in all sites. The effect of E. camadulensis would start with changes in these parameters, which will in turn affect microbial communities by changing their biomass, structure and/or catabolic diversity. The synergistic effect of these changes in soil might resulted in a novel ecological niche in soil which is less favorable to herbaceous plants growth and might probably induce the lack of herbaceous layer under Eucalyptus plants. Our study thus supports the existence of environmental hazards that may result from the use of this exotic plant for reforestation purposes. The present findings should therefore be of great importance for reforestation programs challenging plant biodiversity preservation.

Acknowledgments. This work has been supported by AIRES-Sud 7212 Project (le Ministère Français des Affaires Européennes, MAEE) and a scholarship from Agence Universitaire de la Francophonie (AUF). A part of this work was performed at LEMSAT (Laboratoire d'Ecologie Microbienne des Sols et Agrosystèmes Tropicaux, laboratory certified by International Organization for Standardization ISO 9001 version 2008). We are grateful to Lamine DIENG for his huge contribution to DGGE technical. We thank Boubacar Manneh for helping to improve the English syntax.

\section{REFERENCES}

[1] Anderson, J.P.E., Domsch, K.H. (1978): A physiological method for measurement of microbial biomass in soils. - Soil Biology and Biochemistry 10: 215-221

[2] Aubert, G. (1978) : Méthodes d'Analyse des sols. - Edition CRDP, Marseille, p. 360.

[3] Artursson, V., Finlay, R.D., Jansson, J.K. (2006): Interactions between arbuscular mycorrhizal fungi and bacteria and their potential for stimulating plant growth. Environmental Microbiology 8: 1-10. doi:10.1111/j.1462-2920.2005.00942.x

[4] Bardgett, R.D., Frankland, J.C., Whittaker, J.B. (1993): The effects of agricultural practices on the soil biota of some upland grassland. Agriculture, Ecosystems \& Environment 45: 25-45.

[5] Bernhard-Reversat, F., Loumeto, J.J. (2002): The litter system in African forest tree plantations. - In : Vikram Reddy M, Management of tropical plantation forests and their soil litter system. -Science Publishers, Inc. Enfield (NH, USA) 11-39.

[6] Bernhard-Revesat, F. (1987) : Les cycles des éléments minéraux dans un peuplement de Acacia seyal et leur modification en plantation de Eucalypus au Sénégal. - Acta oecologica, Oecalogia generalis $8: 3-16$.

[7] Berthelot, A., ranger, J., Gelhave, D. (2000): Nutrient uptake and immobilization in shortrotation coppice stand of hybride poplars in North-West France. - Forest Ecology and Management 128: 167-179. 
[8] Biró, B., Köves-Péchy, K., Vörös, I., Takács, T., Eggenberger, P., Strasser, R.J. (2000): Interrelations between Azospirillum and Rhizobium nitrogen fixers and arbuscular mycorrhizal fungi in the rhizosphere of alfalfa in sterile AMF free or normal conditions. - Applied Soil Ecology 15: 159-168.

[9] Blum, U., Shafer, S.R. (1988): Microbial populations and phenolic acids in soil. - Soil Biology and Biochemistry 20: 793-800.

[10] Bouillet, J.P., Nizinski, G., Nzila, J.D., Ranger, J. (1997): The sustainability of Eucalyptus commercial plantation : The Congolese approach. - In: Proceedings IUFRO Meetings 4: 232-237.

[11] Bouillet, J.P., Bernhard-Reversat, F. (2001): General objectives and sites. In: BernhardReversat, F(Ed), Effect of Exotic tree plantation on Plant Diversity and Biological Soil Fertility in the Congo Savanna: A Reference to Eucalyptus. - CIFOR, Bogor, Indonesia, pp.13-21.

[12] Cannell, M.G. (1999): Environmental impacts of forest monocultures: water use, acidification, wildlife conservation, and carbon storage. - New Forests 17(1): 239-262.

[13] Casida, L.E., Klein, D.A., Santoro, T. (1964) : Soil dehydrogenase activity. - Soil Science 98: 371-376.

[14] Cossalter, C., Pye-Smith, C. (2003): Fast-wood Forestry: Myths and Realities. - Center for international Forest Research, Indonesia.

[15] Degens, B.P., Harris, J.A. (1997): Development of a physiological approach to measuring the catabolic diversity of soil microbial communities. - Soil Biology and Biochemistry 9:1309-1320.

[16] Degens, B.P., Schipper, L.A., Sparling, G.P., Duncan, L.C. (2001): Is the microbial community in a soil with reduced catabolic diversity less resistant to stress or disturbance. - Soil Biology and Biochemistry 33: 1143-1153.

[17] Diallo, M.D., Duponnois, R., Guisse, A., Sall, S., Chotte, J.L., Thioulouse, J. (2006): Biological effects of native and exotic plant residues on plant growth, microbial biomass and $\mathrm{N}$ availability under controlled conditions. - European Journal of Soil Science 42: 238-246.

[18] Dellacassa, E., Mendez, P., Cerdeiras, P., Moyna, P. (1989): Antimicrobial activity in Eucalyptus essential oils. - Fitoterpia 60: 544-546.

[19] Dick, R.P., Breakwill, D.,Turco, R. (1996): Soil enzyme activities and biodiversity measurements as integrating biological indicators. - In: Doran, J.W., Jones, A.J. (Eds.), Handbook of Methods for Assessment of Soil Quality. Soil Sci Society of America Specific Publications, Madison, WI: 242-272.

[20] Duponnois, R., Chotte, J.L., Sall, S.N., Cadet, P. (2001): The effect of organic amendments on the interaction between a nematophagous fungus Arthrobotrys oligospora and the roots knot nematodes meloidogyne mayaguensis parasitizing tomato plants. Biology and fertility of soils $34: 1-16$.

[21] Durán, A., García-Préchac, F., Pérez Bidegain, M., Frioni, L., Sicardi, M., Molteni, C., Bozzo, A. (2001): Propiedades físicas, químicas y biológicas. Cap. 2.5. Suelos y Vegetación. - In: Informe Final, Proyecto Monitoreo ambiental de plantaciones forestales en Uruguay, Convenio UDELAR-División Forestal MGAP-Banco Mundial.

[22] Eivazi, F., Tabatabai, M.A. (1977): Phosphatases in soil. - Soil Biology and Biochemistry 9: 67-172.

[23] Fall, S., Nazaret, S., Chotte, J.L., Brauman, A. (2004): Bacterial density and community structure associated with aggregate size fractions of soil-feeding termite mounds. Microbial Ecology 48: 191-199.

[24] Farley, K.A., Pineiro, G., Palmer, S., Jobbagy, E., Jackson, R. (2008): Stream acidification and base cation losses with grassland afforestation. - Water Research 44

[25] Giffard, P.L. (1969):Recherches effectuées sur les Eucalyptus. - Rapport d'activité du CTFT au Sénégal. 
[26] Hamel, O., Bailly, C.R. (1981): Premières observations sur les potentialités de l'Eucalyptus au Sénégal. - Contribution volontaire au Congrès IUFRO de Kyoto - Japon

[27] Hooper, D.U., Bignel, D.E., Brown, V.K., Brussaard, L., Dangerfield, J.M., Wall, D.H., Wardle, D.A., Coleman, D.C., Gille, K.E., Lavelle, P., van der Putten, W.H., de Ruiter, P.C., Rusek, J., Silver, W.L., Tiedje, J.M., Wolters, V. (2000): Interactions between aboveground and belowground biodiversity in terrestrial ecosystems: patterns, mechanisms, and feedbacks. - Bioscience 50: 1049-106.

[28] Kisa, M., Sanon, A., Thioulouse, J., Assigbetse, K., Sylla, S., Spichiger, R., Dien, L., Berthelin, J., Prin, Y., Galiana, A., Lepage, M., Duponnois, R. (2007): Arbuscularmycorrhizal symbiosis can counterbalance the negative infuence ofthe exotic tree species Eucalyptus camaldulensis on the structure and functioning of soil microbial communities in a sahelian soil. - FEMS Microbiology Ecology 62: 32-44.

[29] Kennedy, A.C. (1998): The rhizosphere and spermosphere - In: Sylvia, D.M., Fuhrmann, J.J., Hartel, P.G., Zuberer, D.A. (Eds.) Principles and Applications of Soil Microbiol., Prentice-Hall, Englewood Cliff, NJ, pp. 389-407.

[30] Kourtev, P.S., Ehrenfeld, J.G., Haeggblom, M. (2003): Experimental analysis of the effect of exotic and native plant species on the structure and function of soil microbial communities. - Soil Biology and Biochemistry 35: 895-905.

[31] Laclau, J.P., Ranger, J., Deleporte Nouvellon, Y., Saint-André, L., Marlet, S., Bouillet, J.P. (2005): Nutrient cycling in a clonal stand of Eucalyptus and an adjacent savanna ecosystem in Congo 3. Input-output budgets and consequences for the sustainability of the plantations. - Forest Ecology and Management 210: 375-391.

[32] Laclau, J.P., Toutain, F., Thongo, M'bou, A., Arnaud, M., Joffre, R., Ranger, J. (2004): The function of the superficial root mat in the biogeochemical cycles of nutrients in Congolese Eucalyptus plantations. - Annals of Botany 93: 249-261.

[33] Macheix, J.J., Fleuriet, A., Billot, J. (1990): Fruit phenolics. - CRC Press: Boca Raton, Florida.

[34] Mangelot, F., Toutet, F. (1980) : Les litières. - In : Pesson, P. (Ed.) Actualités d'Ecologie Forestière, Gauthier-Villars, Paris, pp. 3-59.

[35] Maymard, J. (1962) : Les sols de la région de Matam. - SOGETHA, Paris (France), Vol.2. 166p.

[36] Muyzer, G., de Wall, E., Uitterlinden, A. (1993): Profiling of complex microbial populations by DGGE of PCR-amplified genes coding for $16 \mathrm{~S}$ rRNA. - Applied Environmental Microbiology 59: 695-700

[37] Meyer, O. (1994): Functional groups of microorganisms. - In: Schulze, E.D., Mooney, H. (Eds.) Biodiversity and Ecosystem Function, Springer-Verlag, Berlin, pp. 67-97.

[38] Nannipieri, P., Eldor, P. (2009): The chemical and functional characterization of soil N and its biotic components. - Soil Biology and Biochemistry 41: 2357-2369.

[39] Olsen, S.R., Cole, C.V., Watanabe, F.S., Dean, L.A. (1954) : Estimation of available phosphorus in soils by extraction with sodium bicarbonate. U.S. Department of Agriculture circular, vol. 939. U.S. Department of Agriculture, Washington, DC. p. 19.

[40] Pérez Bidegain, M., Garcìa-Préchac, F., Durán, A. (2001): Soil use change effect from pastures to Eucalyptus spp., on some soil physical and chemical properties in Uruguay. In: Proceedings of the 3rd International Conference on Land Degradation, Rio de Janeiro, in CD-ROM.

[41] Pieri, C. (1969) : Etude pédologique de la région de Nioro du Rip au 1/50.000. - IRAT, Dakar, Sénégal.

[42] Powlson, D.S., Brookes, P.C., Christensen, B.T. (1987): Measurement of soil microbial biomass provides and early indication of chances in total soil organic matter due to straw incorporation. - Soil Biology and Biochemistry 19: 159-164.

[43] Rhoades, C., Binkley, D. (1996): Factors influencing decline in soil pH in Hawaiian Eucalyptus and Albizia plantations. - Forest Ecology and Management 80: 47-56. 
[44] Saetre, P., Bååth, E. ( 2000): Spatial variation and patterns of soil microbial community structure in a mixed spruce-birch stand. - Soil Biology and Biochemistry 32: 909-917.

[45] Sanon, A., Martin, P., Thioulouse, J., Plenchette, C., Spichiger, R., Lepage, M., Duponnois, R. (2006): Displacement of an herbaceous plant species community by mycorrhizal and non-mycorrhizal Gmelina arborea, an exotic tree, grown in a microcosm experiment. - Mycorrhiza 16: 125-132.

[46] Sicardi, M., García-Préchac, F., Frioni, L. (2004): Soil microbial indicators sensitive to land use conversion from pastures to commercial Eucalyptus grandis (Hill ex Maiden) plantations in Uruguay. - Applied Soil Ecology 27: 125-133.

[47] Simpson, E.H. (1949): Measurement of diversity. - Nature 163: 688.

[48] Singleton, V.L., Rossi, J.A. (1965): Colorimetry of total phenolics with phosphomolybdic-phosphotungstic acid reagents. - American Journal of Enology and Viticulture 16: 144-158.

[49] Swith, M.J., Heal, D.W., Anderson, J.M. (1979): Decomposition in Terrestrial Ecosystems. - Blackwell Scientific publications, Oxford.

[50] Thioulouse, J., Chessel, D., Dolédec, S., Olivier, J.M. (1997): ADE-4: a multivariate analysis and graphical display software. - Statistics Computing 7: 75-83.

[51] Turnbull, J.W. (1999): Eucalyptus plantation. -New Forest 17: 37-52.

[52] Vivas, A., Moreno, B., del Val, C., Macc, C., Masciandaro, G., Benítez, E. (2008): Metabolic and bacterial diversity in soils historically contaminated by heavy metals and hydrocarbons. - Journal of Environmental Monitoring 10: 1287-1296.

[53] Vivas, A., Moreno, B., Garcia-Rodriguez, S., Benitez, E. (2009): Assessing the impact of composting and vermicomposting on bacterial community size and structure, and microbial functional diversity of an olive-mill waste. - Bioresource Technology 100: 1319-1326.

[54] Wardle, D.A. (2002): Communities and Ecosystems: Linking the aboveground and belowground components. Monographs in Population Biology. - Princeton University Press, Princeton, USA. 34-392.

[55] Yao, H., He, Z., Wilson, M.J., Campbell, C.D. (2000): Microbial biomass and community structure in a sequence of soils with increasing fertility and changing land use. Microbial Ecology 40: 223-237.

[56] Yu, X., Yu, D., Lu, Z., MA, K. (2005): A new mechanism of invader success: Exotic plant inhibits natural vegetation restoration by changing soil microbe community. Chinese Science Bulletin 50: 1105-1112.

[57] Zinn, Y.L., Resck, D.V.S., Da Silva, J.E. (2002): Soil organic carbon as affected by afforestation with Eucalyptus and Pinus in Cerrado region of brazil. - Forest Ecology and Management 166: 287-294. 